\title{
CURRENT AND FUTURE USE OF MANAGEMENT TOOLS
}

\author{
Zlatko Nedelko, Vojko Potocan, Marina Dabić
}

\section{Introduction}

A plethora of management ideas and concepts have been developed in management literature over decades [15], [41], [55], [58], [60]. But those management ideas and concepts are in the literature rarely discussed on the level of their use as a management tool [2], [57]. It is evident that developed ideas and concepts (consequently also tools) are in literature mainly dealt with separately, for the most part as a single tool [14], [21], [24], [36], [42], while some studies consider few tools jointly [25], [40] due to their interrelatedness.

A holistic consideration of the different tools or the plethora of management tools together is rarely found in literature. A longitudinal research aiming to examine trends about use, current use, and percentage of satisfied users for selected tools has been conducted for more than a decade by international research group [47], [48], [49]. Comprehensive studies dealing with more management tools beyond viewpoints considered by this research group do not exist. Partial discussions and empirical investigations about single or a few selected management tools together reveal some differences in patterns of management tools use worldwide. Our contribution continues these discussions in a more comprehensive manner. This paper focuses especially on future use and issues related to the future use of management tools in organizations within catching up countries.

Turning to the impact of previous experiences with management tools use on their future use by employees' in organizations, evidences from everyday life show that previous (positive and negative) experiences importantly influence future use, motivation for use, etc. [1], [8], [54]. Management literature dealing with these issues is rather limited [5], [52]. More often, the impact of previous experiences (with use, participation, observation, etc.) on the behavior of existing or further potential users is considered in various other fields, such as: (1) shopping experiences enjoyment has a significant positive influence upon future customers' intentions to shop [22]; (2) previous experiences with service (e.g., insurance agency, travel agency) influence customers' decisions on future use of services [8], [18]; and (3) the impact of behavior experiences on the desired behavior in organizations (e.g., manager as a role model), etc. [5], [20], [46]. Those examples emphasize the importance of past experiences with use and engagement for future use, engagement, enrolment, retaking service, etc.

In the mainstream of management literature [13], [15], [53], the link between previous working experiences (e.g., about working and behavior) and future behavior is not explicitly considered. This link gets more attention in the field of organizational behavior [5], [28], [52] and work psychology [3], [34]. Very often the examination of the link between attitudes and behavior is based on the theory of planned behavior, first introduced by [1]. Those cognitions are the groundwork for our discussion.

Based on the above findings, we presuppose that the management tools used in organizations are importantly dependent upon the previous experiences of other users (e.g., co-workers, managers). Those experiences can importantly influence an employee's perception about motivation for the use of management tools. This consequently results in an employee's action to either use or not use.

In the framework of a more holistic agenda for consideration of management tools use and their future use, this paper focuses on: (1) differences in management tools use among employees in Slovenian and Croatian organizations; (2) examination of the links between employees' previous experiences 
with management tools use and its future use (we consider future use either as (a) a desire to use those tools among employees who are already familiar with single tools or (b) a desire to become familiar with management tools among employees who do not know a single management tool yet); and (3) determining patterns of management tools for future use in Slovenia and Croatia (as examples of catching up countries) based on experiences from highdeveloped market economies.

\section{Literature Review}

\subsection{Management Tools}

Management development has gone through several distinctive phases [13], [60]. In each phase, numerous management ideas and concepts have been developed [2], [57], [58]. Use and understanding of management ideas are rather different in literature and business practice. In the process of management concepts use, a different level of management ideas for conceptualization and realization has occurred, ranging from 1) concept - as a rather comprehensive, developed, and defined basis for consideration of an idea; 2) methodology - as an entity or closely related collection of methods, rules, and disciplinary postulates; 3) methods - as goal- and problem-ordered types of procedures, these are especially regular and systemic ways of setting and realizing the given goal; 4) techniques - as the manner in which technical details are treated; to 5) necessary tools, known also as instruments [10], [41], [47], [50], [51], [62].

Management tools involve set of concepts, processes, exercises, and analytical frameworks. This definition was coined by [47] and it is based on his survey of management tools. A general management literature [13], [50], [53], as well as some other management authors using the term management tool [33], [40], does not define it.

Building on the above findings, a management tool can be defined as an entity of instruments to support implementation of concepts and ideas at all levels of conceptualization and realization of concepts, ultimately aiming to support organizational processes.

Rigby and his peers proposed a typology of management tools, defining four groups of management tools. A typology is framed in a matrix, having two dimensions: (1) use of management tools and (2) percentage of satisfied users. This typology classifies management tools according to the mean values of use and satisfaction obtained in research [47], [48], [49]. Due to the lack of comprehensive management tools studies in literature, there is no general valid or contentrelated classification of management tools.

In searching for a content-related classification, known management tools can be organized into two groups based on a historical development of concepts, current use, and their potential to use. The first group encompasses traditional management tools that had been developed in earlier management development phases. The majority of those tools are today well-known and most widely globally used tools, like benchmarking, strategic planning, mission and vision statements, customer relationship management, outsourcing, the balanced scorecard, and customer segmentation [47], [48], [49]. Literature reveals that globally most used tools are aimed to support customer satisfaction (e.g., customer relationship management, customer segmentation) [27], [45], followed by those supporting the long-term and clear future development of an organization (e.g., strategic planning, mission and vision statements) [25], [36], [40], supporting competitive comparing (e.g., benchmarking) [11], [24], and supporting optimization processes in an organization (outsourcing, core competencies, business process reengineering) [21], [42], [43]. There is also evidence about decreasing the use of some traditional tools. For example, the popularity of business process reengineering has fallen in the last two decades due to numerous unsuccessful reorganizations of business processes [14], [40], [49]. Also total quality management, first treated as a potential source of sustainable competitive advantage [42], has become less used when its use did not result in sustainable profitability [40], [49].

In the second group are contemporary tools. A brand new management concept or tool is rarely found, since the majority of tools have their roots in earlier phases of management development [41]. This group encompasses tools for which tool evolvement is significantly based upon either information technology development or supporting an existing management concept with information technology. This group also encompasses tools developed in later phases of management 
development. Furthermore, supporting existing management concepts with information technology, results in a higher potential for this concept [6], [41]. Typical representatives of this group are, for example, shared service centers - aiming to a set of activities (e.g. HRM activities) under one roof for selected organizational parts [19]. A really new tool could be characterized as a corporate blog, since its serious use is a recent phenomena [39]. Organizations use blogs for direct communication with their target population, information dissemination, brand loyalty development, etc. [39]. Further, radio frequency identification has become a widely used tool (especially in supply chains) since it enables acquiring data of any entity that can be psychically tagged and wirelessly scanned [35]. Also relatively new are loyalty management and consumer ethnography [32]. For example, knowledge management gets a very new dimension of use when electronic databases are used to store knowledge and interfaces enable easier knowledge capture and its dissemination [6].

An overview of relevant literature suggests that there are numerous partial discussions about management tools, especially those most widely used. Those discussions are in majority limited to dealing with single management tools and in the framework of selected purpose of discussion, either theoretical, empirical, or both. A comprehensive study of management tools is known by Bain Research Group [47], [48], [49], which examine the use of management tools in different worldwide regions, users satisfaction, and selected issues regarding tools implementation. There is no evidence about the discussions dealing with the patterns of management tools use in different areas and examining reasons for differences in use.

Literature offers different viewpoints for researching future use of management tools [1], [3], [41], [58], [61]. We put our focus on the impact of previous users' experiences (considered on the basis of current use) with management tools use on future use of management tools by organizational members.

\subsection{Previous Experiences with Management Tools Use and Their Future Use}

Observed behavior in organizations is only a visible response that is the result of the impact of interrelated factors that influence employees' behavior. Literature offers different propositions of what drives employees' behavior. Employees' behavior is driven by: (1) the impact of their personal values [17], [54], and (2) the joint impact of cognitive base and personal values [20]. [1] explains that employees' behavior is based on the link between attitudes and behavior, known as theory of planned behavior.

Different well-known models have aimed to explain the impact of different stimuli on employees' behavior [1], [5], [37] and have several basic building blocks for explaining (future) behavior: (1) employees' own observations (e.g., various stimuli from the environment and from inside of the organization and information about experiences/observations from peers/colleagues), (2) perception considered as a cognitive process that enable employees' interpretation and understanding of its surroundings, and (3) a response that translates perception into actual behavior.

From existing models, we used for our research the model of the information-perception-action (IPA) process, which suggests that employees first get information from their surroundings (e.g. coworkers, managers), that motivate, direct, or influence their behavior. Next is the perception phase, in which employees attach meaning to the available information and experiences. Then the perception, which is based on information, results in actual behavior [4]. According to the purpose of this paper, presumptions about the impact of current use (i.e., experiences with use) of management tools on future use are based on [1]'s theory of planned behavior and the cognitions about the IPA link, as suggested by [16] and later modified by [5]. Next, we examine each IPA model phase in more detail.

The first phase of the IPA link is gathering information. In this phase, employees observe other users and also gather information about experiences with management tools use by themselves. The main sources for obtaining information are especially other users' experiences with management tools use in an organization (e.g., managers, coworkers). Dispatching positive signals about management tools and their beneficial use (by organizational members) is most important in the process of influencing others and their intentions to use tools. In this process, also, management plays an important role, since it gives signals about use and satisfaction with single management tools to the other members of the organization through formal and informal communication [13], [15], [50], [53]. In terms of informal communication, 
for example, management by wandering around could carry over their experiences with management tools to other employees. Another informal communication technique is grapevine, which is typically represented by (1) a gossip chain, where one employee tells many other employees, and (2) cluster chain, where a few employees tell selected others. Those are important channels to disseminate signals of management tools use.

In current-day organizations, important sources of information about experiences with use of management tools in organizations include recommendations, cognitions, instructions, requirements, etc., from different types of organizational channels. Most common are organizational forums, an organizational intranet, and an organizational knowledge repository. Employees can also obtain information about experiences with management tools outside their organizations (e.g., scientific publications, surveys, forums, and social networks). After having gathered a sufficient level of information, the phase of perception is set out.

In the second phase, the main purpose is to determine selected important findings about current management tools used in an organization. In that framework, several basic questions must be answered, like (1) for what purpose/work has the management tool been used?; (2) what are the requirements and preconditions for use of management tools (e.g., in terms of its availability, needed knowledge for activation); and (3) who uses management tools, for what work, and in which areas of working?

The perception process, where an individual creates one's own picture about current use of management tools, is importantly dependent upon an entity of (1) subjective starting points of employees - namely personal values, culture, ethics, and norms, (2) as well as on rational factors related mainly to the availability of management tools, requirements for management tools use, etc. Created picture than represent a base for an action - i.e., intended behavior.

The third phase of the IPA process is action. The perception of gathered information about management tools use results in actual behavior. It is evidently that people use practices that are proven to be good [3], [53] or have positive signals of others in favor of its usage in an organization (e.g. managers) [20], [46]. Based on perceptions about management tools use, employees' actions - according to our research problem - will include the following actions: (1) the desire to use management tools among those employees who already know a single management tool, and (2) the desire to become familiar with management tools among those employees who do not know a single management tool. A future use of those organizational members that already use management tools is not considered.

\section{Research Design}

In the literature, discussions prevail dealing with single management tools [13], [14], [40], [43], [57], while groundwork in this field has been done by Bain research group [47], [48], [49] with examining use, satisfaction, and trends of management tools use for more than a decade. Our research upgrades existing findings and provides a deeper understanding of the linkage between current use and future use of management tools [12], [41]. Our research is also aimed at identifying current and future patterns of management tools in catching up countries. In that framework, we:

- Expanded the scope of researching management tools. In the first part of the questionnaire, respondents have to decide about each management tool whether they: (1) know it and use it (and whether they are satisfied or dissatisfied with the tool use), (2) know it, but don't use it (and whether they want to use the tool or do not need the tool for their work), or (3) do not know it (and whether they want to get familiar with a tool or do not need the tool for their work).

- Asked respondents about issues related to management tools implementation, the need for tools and education about their use, the duration of using management tools, the criteria for selecting tools, and possible improvements due to the management tools use implementation. In the third part of the questionnaire, we collect demographical data.

- Examined the influence of the current use of management tools on future use of management tools (1) by employees who are already familiar with management tools, and (2) those who want to become familiar with management tools.

- Examined the influence of the percentage of satisfied users on the future use of management tools (1) by employees who are already familiar with management tools, 
and (2) those who want to become familiar with management tools.

- Compared the obtained results for Slovenia and Croatia, as well as with existing literature.

- Discussed future patterns of management tools use in catching up economies (e.g., evidence from two former transition countries), based on experiences from high-developed economies.

- Included in the survey were 25 management tools, which were in the last decade most frequently mentioned in management literature.

- Based our analysis procedures on structural equation modeling.

\subsection{Research Model}

The main predisposition underlying our hypotheses is related to the impact of previous experiences on the future use of management tools of those employees who either desire to start using a tool or become familiar with a single management tool. We presuppose that employees' previous experiences with use and satisfaction with management tools importantly influence their desire to use and become familiar with management tools (i.e., future management tool use).

In the model are hypothesized relationships between the following entities of our research about management tools in Slovenia and Croatia: (1) use of management tools, (2) share of satisfied users, (3) desire to use by those employees who already know a management tool, and (4) desire to become familiar by those employees who do not know management tools. The hypothesized relationships are presented in Figure 1. The causal model in Figure 1 presents the impact of current management tools use and the percentage of satisfied users who use management tools, on desire to use management tools and on desire to become familiar with management tools (i.e., future management tools use).

\section{Fig. 1: Hypothesized model}

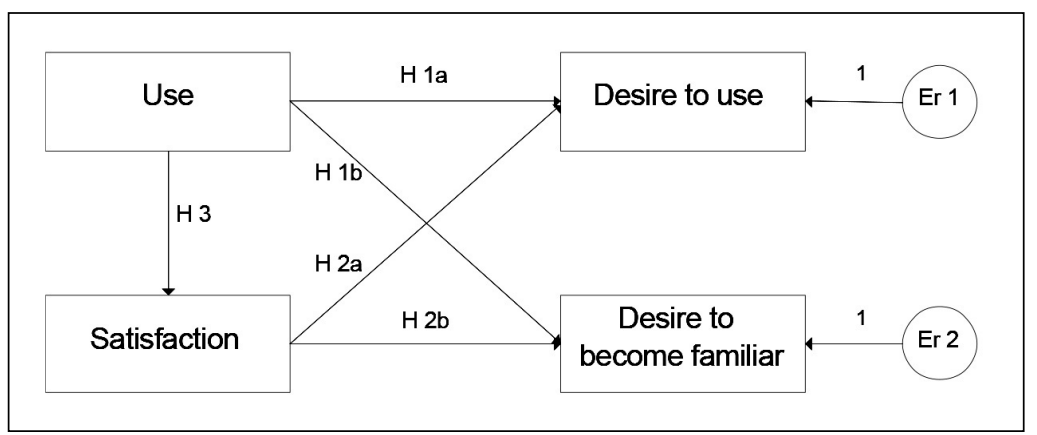

Source: own

\subsection{Research Hypotheses and Research Question}

Based on the presented causal model, the following hypotheses were postulated:

- H 1: The current use of management tools is positively associated with the future use of management tools.

- H 1a: The use of management tools has a significant and positive impact on the desire to use management tools for those organizational members who are already familiar with management tools.
- H 1b: The use of management tools has a significant and positive impact on the desire to become familiar with management tools for those organizational members who are not familiar with management tools.

- H 2: The current satisfaction with the use of management tools is positively associated with the future use of management tools.

- H 2a: The share of satisfied users has a significant and positive impact on the desire to use management tools for those organizational members who are already familiar with management tools. 
- H 2b: The share of satisfied users has a significant and positive impact on the desire to become familiar with management tools for those organizational members who are not familiar with management tools.

- H3:The use of management tools and share of satisfied users are positively associated.

In line with the aims of our paper, we also postulated the following research question: "The pattern of management tools use differs in organizations operating in catching up economies and high-developed market economies."

\subsection{Methods Used}

Normality tests reveal that majority variables in research do not markedly violate the assumptions about normal distribution [23], [31]. For the research question - comparing the pattern of management tools use worldwide - descriptive statistics were used (i.e., mean values). The examination of relations between current and future use is based upon structural equation modeling techniques, as suggested by [7].

\subsection{Data Used}

Data were collected in year 2010 in Slovenia and Croatia. Altogether, we sent 1,500 questionnaires to organizations, respectively 750 in Slovenia and 750 in Croatia. The target population was management, regardless of its hierarchical position. In Slovenia, we got back 210 answers and in Croatia 223 answers. Considered were only returned questionnaires, which had very few missing data. We included in the analysis 155 Slovenian and 185 Croatian questionnaires. This resulted in a respondent rate of $28.0 \%$ for Slovenia and $29.7 \%$ for Croatia, whereas the overall response rate was $28.9 \%$. Regarding considered questionnaires, the respondent rate was respectively $20.7 \%$ and $24.7 \%$, while the overall response rate was $22.7 \%$. For both countries, the organizations included present representative sample (i.e., representative regional coverage; the sample met the basic activity structure of organizations in the country, with a good fit to the industrybased structure of the national economy).

\subsection{Sample Characteristics}

Some basic mean values that characterize both samples are:
- An average age is 44.35 years for Slovenian respondents and 36.90 years for Croatian respondents;

- Slovenian respondents have on average 20.49 years of working experiences, while their Croatian counterparts on average 13.69 years; and

- Slovenian respondents work in a current organization on average 9.03 years, while their Croatian counterparts on average 9.56 years.

A detailed demographic of survey respondents in Slovenia and Croatia is outlined in Table 1.

\section{Results}

\subsection{Results - Descriptive Statistics}

Results about knowing and using management tools, the share of satisfied users, the desire to use management tools, and the desire to become familiar with a single management tool for employees in Slovenian and Croatian organizations are outlined in Table 2.

Based on an in-depth analysis of results regarding knowing and using a single management tool, it is evident that:

- Outsourcing is the most known and used management tool in Slovenia, while in Croatia it is not ranked among the top five management tools.

- In Croatia, the most known and used management tool is mission and vision statements, while in Slovenia it is not ranked among the top five management tools.

- After outsourcing in Slovenia and mission and vision statements in Croatia, the most used management tools in both countries are benchmarking and core competencies.

- Several tools are used significantly more in Slovenian that in Croatia, like outsourcing, knowledge management, total quality management, the balanced scorecard, business process reengineering, mergers and acquisitions, corporate blogs, strategic alliances, six sigma, lean operations, etc.

- Only a few tools are more frequently used in Croatia than in Slovenia, like mission and vision statements, customer relationship management, customer segmentation, shared service centers, etc.

Table 3 presents ranks for the top 10 most used tools in Slovenia and Croatia. 
Tab. 1: Demographic profile of the respondents in survey

\begin{tabular}{l|c|c|l|c|c} 
Gender & Slovenia & Croatia & Organization size & Slovenia & Croatia \\
\hline Male & $48.4 \%$ & $48.1 \%$ & Micro (<9) & $13.5 \%$ & $7.0 \%$ \\
\hline Female & $51.6 \%$ & $51.9 \%$ & Small $(10-49)$ & $18.7 \%$ & $8.1 \%$ \\
\hline Education & & & Medium $(50-249)$ & $43.9 \%$ & $23.8 \%$ \\
\hline Secondary school & $4.2 \%$ & $9.2 \%$ & Large $(>250)$ & $23.9 \%$ & $61.1 \%$ \\
\hline Bachelor degree & $56.9 \%$ & $61.4 \%$ & Department & & \\
\hline Master/Ph.D. & $38.9 \%$ & $29.3 \%$ & Research \& development & $3.2 \%$ & $17.0 \%$ \\
\hline Type of education & & & Fundamental processes & $25.3 \%$ & $24.7 \%$ \\
\hline Humanistic & $2.8 \%$ & $1.1 \%$ & Accounting & $14.9 \%$ & $4.4 \%$ \\
\hline Social & $68.3 \%$ & $58.7 \%$ & Marketing & $11.7 \%$ & $8.8 \%$ \\
\hline Natural and technical & $20.7 \%$ & $34.2 \%$ & Board of directors & $29.2 \%$ & $37.4 \%$ \\
\hline Other & $8.3 \%$ & $5.9 \%$ & Other & $15.6 \%$ & $7.7 \%$ \\
\hline Position & & & Economy sector & & \\
\hline Specialists & $40.7 \%$ & $44.3 \%$ & Primary & $1.9 \%$ & $1.1 \%$ \\
\hline Low management & $8.7 \%$ & $12.6 \%$ & Secondary & $27.7 \%$ & $18.6 \%$ \\
\hline Middle management & $32.0 \%$ & $24.6 \%$ & Tertiary & $43.2 \%$ & $71.6 \%$ \\
\hline Top management & $12.7 \%$ & $10.9 \%$ & Quaternary & $27.1 \%$ & $8.7 \%$ \\
\hline CEO & $6.0 \%$ & $7.7 \%$ & & & \\
\hline
\end{tabular}

Source: own survey in Slovenia and Croatia

\begin{tabular}{|c|c|c|c|c|c|c|c|c|}
\hline \multirow{3}{*}{$\begin{array}{l}\text { Tab. 2: } \begin{array}{l}\text { Current use, } \\
\text { and Croatia }\end{array} \\
\text { Management tools }\end{array}$} & \multirow{2}{*}{\multicolumn{2}{|c|}{$\begin{array}{c}\text { Usage and } \\
\text { knowing } \\
\text { of tools }\end{array}$}} & \multirow{2}{*}{\multicolumn{2}{|c|}{ Satisfied users }} & \multirow{2}{*}{\multicolumn{2}{|c|}{ Desire to use }} & \multirow{2}{*}{\multicolumn{2}{|c|}{$\begin{array}{l}\text { Desire to } \\
\text { become familial }\end{array}$}} \\
\hline & & & & & & & & \\
\hline & SLO & CRO & SLO & CRO & SLO & CRO & SLO & CRO \\
\hline Strategic Planning & 87.1 & 79 & 90.6 & 70.7 & 58.5 & 69.1 & 75.0 & 81.6 \\
\hline $\begin{array}{l}\text { Customer Relationship } \\
\text { Management }\end{array}$ & 77.4 & 78.4 & 87.5 & 85.7 & 43.8 & 58.0 & 65.7 & 90.0 \\
\hline Customer Segmentation & 69.3 & 74 & 97.3 & 90.1 & 43.5 & 48.4 & 52.2 & 72.9 \\
\hline Benchmarking & 88.4 & 78.3 & 94.7 & 87.6 & 71.0 & 73.1 & 55.6 & 92.5 \\
\hline $\begin{array}{l}\text { Mission and Vision } \\
\text { Statements }\end{array}$ & 69 & 88.6 & 80.0 & 85.3 & 65.4 & 33.3 & 43.5 & 33.3 \\
\hline Core Competencies & 72.3 & 77.3 & 88.6 & 75.9 & 66.7 & 76.9 & 54.8 & 66.7 \\
\hline Outsourcing & 89.7 & 76.2 & 95.5 & 71.6 & 47.1 & 37.7 & 42.9 & 47.7 \\
\hline $\begin{array}{l}\text { Business Process } \\
\text { Reengineering }\end{array}$ & 71.6 & 45.4 & 87.2 & 94.6 & 64.1 & 48.9 & 46.3 & 54.5 \\
\hline $\begin{array}{l}\text { Scenario and } \\
\text { Contingency Planning }\end{array}$ & 54 & 42.9 & 65.7 & 94.9 & 37.0 & 76.3 & 45.3 & 77.9 \\
\hline Knowledge Management & 79 & 65.7 & 86.2 & 85.5 & 69.1 & 78.6 & 54.8 & 65.1 \\
\hline
\end{tabular}




\begin{tabular}{|c|c|c|c|c|c|c|c|c|}
\hline $\begin{array}{l}\text { Current use, } \\
\text { and Croatia ( }\end{array}$ & $\begin{array}{l}\text { tisfac } \\
\%)(p\end{array}$ & $\begin{array}{l}n \text {, an } \\
\text { 2) }\end{array}$ & ture & of $n$ & & 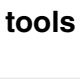 & Slo & \\
\hline \multirow[t]{2}{*}{ Management tools } & \multicolumn{2}{|c|}{$\begin{array}{c}\text { Usage and } \\
\text { knowing } \\
\text { of tools }\end{array}$} & \multicolumn{2}{|c|}{ Satisfied users } & \multicolumn{2}{|c|}{ Desire to use } & \multicolumn{2}{|c|}{$\begin{array}{l}\text { Desire to } \\
\text { become familiar }\end{array}$} \\
\hline & SLO & CRO & SLO & CRO & SLO & CRO & SLO & CRO \\
\hline Strategic Alliances & 64.5 & 36.5 & 80.8 & 92.9 & 40.5 & 35.3 & 38.2 & 55.2 \\
\hline Balance Scorecard & 61.7 & 50.5 & 98.1 & 79.4 & 51.2 & 50.0 & 56.9 & 66.7 \\
\hline $\begin{array}{l}\text { Supply Chain } \\
\text { Management }\end{array}$ & 62.6 & 52.7 & 85.7 & 94.4 & 27.5 & 44.1 & 35.1 & 23.3 \\
\hline Growth Strategies Tools & 50.9 & 34.4 & 81.0 & 93.3 & 60.3 & 69.6 & 46.7 & 57.1 \\
\hline $\begin{array}{l}\text { Total Quality } \\
\text { Management }\end{array}$ & 85.8 & 63.4 & 90.5 & 58.3 & 50.0 & 52.3 & 59.1 & 62.7 \\
\hline Shared Service Centers & 39 & 42.6 & 60.0 & 71.9 & 18.0 & 50.0 & 26.1 & 53.8 \\
\hline Lean Operations & 50.4 & 13.6 & 90.0 & 100 & 26.5 & 55.0 & 36.5 & 55.1 \\
\hline Collaborative Innovation & 51.3 & 28.4 & 84.2 & 68.4 & 71.7 & 73.3 & 55.4 & 64.6 \\
\hline Loyalty Management & 64.6 & 45.1 & 76.7 & 76.0 & 53.6 & 55.4 & 52.7 & 81.0 \\
\hline Mergers and Acquisitions & 76.8 & 54.4 & 82.8 & 88.9 & 27.0 & 30.3 & 42.9 & 44.4 \\
\hline Six Sigma & 42.2 & 32.3 & 82.4 & 90.0 & 35.4 & 58.3 & 49.4 & 57.4 \\
\hline Offshoring & 40 & 34.4 & 66.7 & 85.7 & 32.1 & 39.6 & 38.5 & 42.0 \\
\hline Consumer Ethnography & 40.6 & 32.4 & 85.7 & 93.8 & 34.7 & 71.4 & 40.2 & 47.5 \\
\hline Corporate Blogs & 50.9 & 44.8 & 96.3 & 84.2 & 45.1 & 50.8 & 46.7 & 46.5 \\
\hline $\begin{array}{l}\text { Radio Frequency } \\
\text { Identification }\end{array}$ & 31 & 23.5 & 63.6 & 80.0 & 29.7 & 50.0 & 38.1 & 41.3 \\
\hline
\end{tabular}

Tab. 3: Top 10 most used tools in Slovenia and Croatia
\begin{tabular}{c|l|c|c|l|c} 
Rank & \multicolumn{1}{|c}{ Management tool (Slovenia) } & $\%$ & & \multicolumn{1}{|c}{ Management tool (Croatia) } & $\%$ \\
\hline 1. & Outsourcing & 57 & & Mission and Vision Statements & 61 \\
\hline 2. & Benchmarking & 48 & & Benchmarking & 49 \\
\hline 3. & Core Competencies & 45 & & Core Competencies & 48 \\
\hline 4. & Knowledge Management & 43 & & Customer Relationship Management & 39 \\
\hline 5. & Total Quality Management & 41 & & Customer Segmentation & 39 \\
\hline 6. & Mission and Vision Statements & 36 & & Outsourcing & 38 \\
\hline 7. & Customer Relationship Management & 36 & & Knowledge Management & 34 \\
\hline 8. & Strategic Planning & 34 & & Strategic Planning & 33 \\
\hline 9. & Balance Scorecard & 34 & & Total Quality Management & 27 \\
\hline 10. & Business Process Reengineering & 30 & & Business Process Reengineering & 21 \\
\hline & & & & Scenario and Contingency Planning & 21 \\
\hline
\end{tabular}




\subsection{Results - Hypotheses Testing}

We tested the proposed hypotheses in the research model for Slovenia and Croatia for aggregated data, not for a single management tool. In the interest of space, we outlined the standardized estimates regarding regression weights, correlations, and squared multiple correlations. The results for the Slovenian sample are outlined in Figure 2 and for the Croatian sample in Figure 3.

\section{Fig. 2: Hypothesis testing - Slovenian sample}

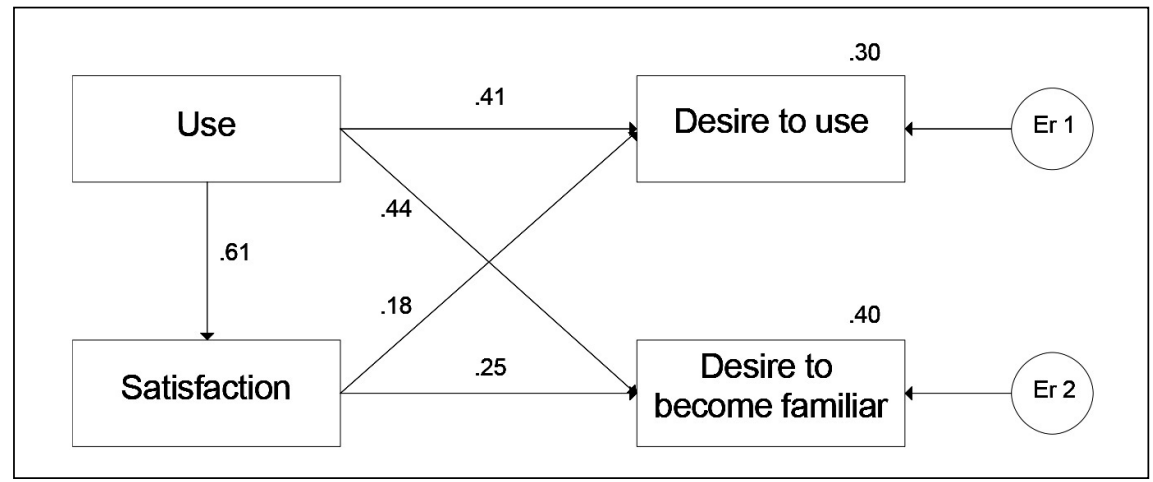

Source: own

\section{Fig. 3: Hypothesis testing - Croatian sample}

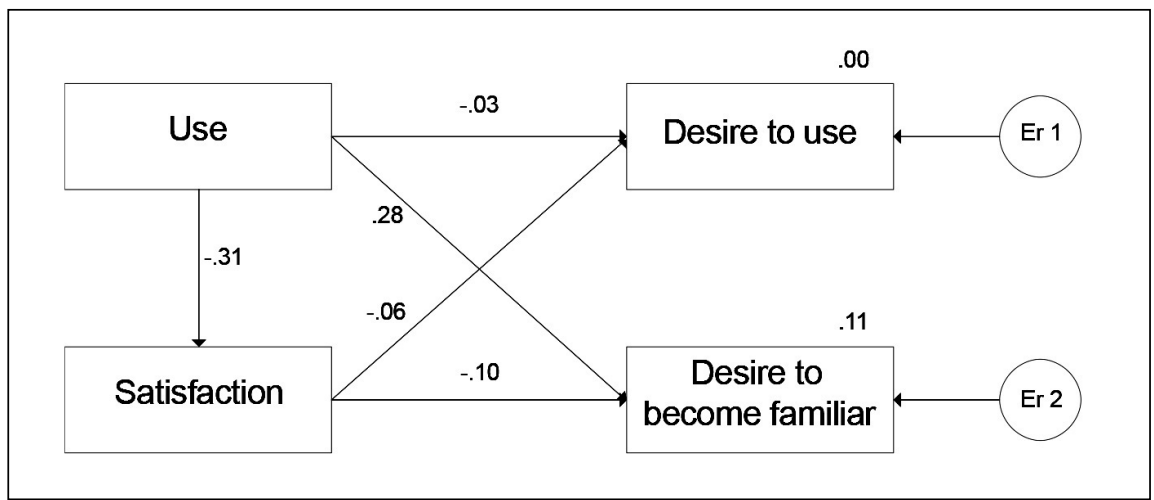

Source: own

Management tools use. Management tools use has a relatively strong and positive, even though insignificant, effect on the desire to use management tools for those who already know management tools in Slovenia $(\beta=0.415, p>0.05)$. This means that as the management tool use increases, so does the desire to use them by those who already know a single management tool but do not yet use them. Management tools use has a relatively strong and significant effect on the desire to become familiar with management tools for those who do not know management tools in Slovenia $(\beta=0.442, p<0.05)$. This means that as the management tool use increases, so does the desire to become familiar with them 
for those employees who do not know them yet. Management tools use is related to users' satisfaction with management tools in Slovenia ( $\beta=0.608, p<0.05)$. We can conclude that as single management tool use increased, so does the number of satisfied users in an organization. These results support hypotheses $1 \mathrm{~b}$ and 3 for Slovenia, while rejecting hypothesis 1 a.

In the Croatian sample, management tools use is not significantly related to (1) a desire to use management tools for those who already know management tools in Croatia $(\beta=-0.010$, $p>0.05)$. This means that an increased use of management tools does not lead to an increased percentage of an organization's members who want to use a management tool among those who already know management tools; (2) a desire to become familiar with management tools for those who do not know management tools in Croatia $(\beta=0.283$, $p>0.05$ ); and (3) users' satisfaction with management tools in Croatia $(\beta=-0.307$, $p>0.05)$. This leads to the conclusion that an increased use of management tools does not lead to an increased number of satisfied users. These results reject hypotheses $1 \mathrm{a}, 1 \mathrm{~b}$, and 3 for the Croatian sample.

Share of satisfied users with management tools. Satisfaction with management tools use (i.e., considered as a percentage of satisfied users) has a positive, but insignificant effect on (1) the desire to use management tools for those employees who are already familiar with management tools in Slovenia $(\beta=0.181$, $p>0.05)$; (2) and on the desire to become familiar with management tools for those who do not know management tools in Slovenia $(\beta=0.253, p>0.05)$. Thus, hypotheses $2 a$ and $2 b$ are not supported for the Slovenian sample. Satisfaction with management tools use is not significantly related to the desire to use management tools for those organizational members who are already familiar with management tools in Croatia $(\beta=-0.058$, $p>0.05$ ), and to the desire to become familiar with management tools for those who do not know management tools in Croatia $(\beta=-0.104$, $p>0.05$ ). Thus, hypotheses $2 a$ and $2 b$ are not supported.

The squared multiple correlations show that $30 \%$ of the variance in the desire to use management tools for those Slovenian employees who already know a single management tool can be explained by the joint influence of the use and satisfaction. Thus, $70 \%$ of the variation in desire to use management tools cannot be explained with the model. On the other hand, the results reveal that use and satisfaction cannot explain variation in desire to use management tools among Croatian employees. Further, the results indicate that $40 \%$ of the variance in the desire to become familiar with a single management tool for Slovenian employees can be explained by the joint influence of the use and satisfaction. Thus, $60 \%$ of the variation in desire to become familiar with a single management tool is unexplained by two considered factors. On the other hand, for the Croatian sample only $11 \%$ of the variation in desire to become familiar could be explained by the joint influence of use and satisfaction. The remaining $89 \%$ of the variation in desire to become familiar cannot be explained by two considered factors.

\subsection{Results - International Comparison}

A comparison of single management tools use in different regions reveals different ranks in different regions. At first glance, it is evident that the worldwide most used management tools are not among the most used in organizations in former transition economics in Central and Eastern Europe (i.e., studied examples of Slovenia and Croatia) and vice versa. The detailed results are outlined in Table 4. 


\section{Tab. 4: Use of management tools worldwide ${ }^{a}$}

\begin{tabular}{|c|c|c|c|c|c|c|c|c|}
\hline \multirow[b]{2}{*}{ Management tool } & \multicolumn{8}{|c|}{ Use of management tools } \\
\hline & $\begin{array}{l}\mathrm{GL}- \\
2006\end{array}$ & $\begin{array}{l}\mathrm{GL}^{*}- \\
2008\end{array}$ & NA & EU & AP & LA & CRO & SLO \\
\hline Strategic Planning & 1 & 2 & 1 & 1 & 2 & 1 & 8 & 8 \\
\hline $\begin{array}{l}\text { Customer Relationship } \\
\text { Management }\end{array}$ & 2 & 4 & 3 & 4 & 1 & 9 & 4 & $6(\mathrm{t})$ \\
\hline Customer Segmentation & 3 & 7 & 6 & $2(t)$ & 3 & $3(t)$ & 5 & 11 \\
\hline Benchmarking & 4 & 1 & 2 & $2(\mathrm{t})$ & $9(\mathrm{t})$ & 2 & 2 & 2 \\
\hline Mission and Vision Statements & 5 & 3 & 4 & 7 & $5(t)$ & 5 & 1 & $6(t)$ \\
\hline Core Competencies & 6 & 9 & 5 & $5(t)$ & 4 & 10 & 3 & 3 \\
\hline Outsourcing & 7 & 5 & 8 & $5(\mathrm{t})$ & $7(\mathrm{t})$ & $3(t)$ & 6 & 1 \\
\hline $\begin{array}{l}\text { Business Process } \\
\text { Reengineering }\end{array}$ & 8 & 8 & $10(t)$ & $10(t)$ & $5(t)$ & $14(t)$ & $10(t)$ & 10 \\
\hline $\begin{array}{l}\text { Scenario and Contingency } \\
\text { Planning }\end{array}$ & 9 & 13 & 9 & 8 & 14 & 7 & $10(t)$ & 12 \\
\hline Knowledge Management & 10 & 14 & 12 & $10(t)$ & $7(\mathrm{t})$ & $14(t)$ & 7 & 4 \\
\hline Strategic Alliances & 11 & 11 & 7 & 9 & 13 & 13 & 20 & 17 \\
\hline Balanced Scorecard & 12 & 6 & $13(t)$ & 13 & 12 & $11(t)$ & 13 & 9 \\
\hline Supply Chain Management & 13 & 12 & $13(t)$ & $14(t)$ & 11 & $11(t)$ & 12 & 15 \\
\hline Growth Strategies Tools & 14 & 16 & $10(t)$ & $10(t)$ & $15(t)$ & 6 & 19 & 18 \\
\hline Total Quality Management & 15 & 17 & $18(t)$ & $14(t)$ & $9(\mathrm{t})$ & 8 & 9 & 5 \\
\hline Shared Service Centres & 16 & 15 & $18(t)$ & 19 & $15(t)$ & 16 & 14 & $23(t)$ \\
\hline Lean Operations & 17 & - & 15 & $17(t)$ & $18(t)$ & 19 & 25 & $23(t)$ \\
\hline Collaborative Innovation & 18 & 22 & 16 & 20 & $18(t)$ & 18 & 17 & 19 \\
\hline Loyalty Management & 19 & 24 & 21 & $17(\mathrm{t})$ & 17 & $20(t)$ & 15 & 13 \\
\hline Mergers and Acquisitions & 20 & 10 & 17 & $14(t)$ & 22 & 17 & $22(t)$ & 14 \\
\hline Six Sigma & 21 & - & 22 & 23 & 20 & $20(t)$ & $22(\mathrm{t})$ & 20 \\
\hline Off shoring & 22 & - & $18(t)$ & 21 & 24 & 24 & 24 & 25 \\
\hline Consumer Ethnography & 23 & - & $23(t)$ & 22 & 21 & 22 & 18 & 21 \\
\hline Corporate Blogs & 24 & - & $23(t)$ & 24 & 23 & 25 & 16 & 16 \\
\hline Radio Frequency Identification & 25 & - & 25 & 25 & 25 & 23 & 21 & 22 \\
\hline
\end{tabular}

a Note: Data for Global average (GL) 2006 and 2008, North America (NA) 2006, European Union 15 (EU) 2006), Asia Pacific (AP) 2006), and Latin America (LA) 2006 are calculated upon the results from management tools research [48, 49]. Data for Slovenia and Croatia are from our research. 


\section{Discussion}

The main purpose of this paper was to examine the linkages between current and future use of management tools and to discuss future patterns of management tools use in catching up countries, with an emphasis on experiences from two former transition economics - Slovenia and Croatia. An overview of the literature about well-known and most used management tools reveals that discussions dealing with single management tools are often focused on a special theme and specific purpose according to the circumstances of discussion [14], [24], [32], [42], [43]. From the viewpoint of linkage between current and future use of management tools, there is no equivalent or similar approach in the literature.

Our findings about the impact of current use (in terms of experiences) on future management tools use are in line with general cognitions in literature that previous experiences (e.g., with use, observations) importantly influence future behavior (e.g., future use) [22], [46], as well as with cognitions that co-workers' previous experiences (e.g., with use) can influence other co-workers' decisions about their future behavior (e.g., future use) [3], [5], [9], [34]

The relation between the share of satisfied users and future intentions to use management tools do not reveal an important association in Slovenia and Croatia. Generally looking, the impact of satisfied users on future management tools use is insignificant. More specifically, for the Slovenian sample, it is evident that the impact of the percentage of satisfied users on future management tools is positive, weak, and insignificant, while inversely in the Croatian organizations the impact is negative, and also very weak and insignificant. Also, the literature offers very little empirical evidence about the impact of satisfaction on future use [22], [46], since in the forefront of this field of researching are experiences with use, observations, and recommendations [3], [9].

It is evident that, based on current management tools use and the percentage of satisfied users, the proposed model explains a relatively higher percentage of the variance in employees' desire to become familiar with single management tools (i.e. $40 \%$ for Slovenia and $11 \%$ for Croatia) than the variance in employees' desire to use management tools (i.e. 30\% and 0\%, respectively). The explanation power is significantly greater for the Slovenian than the Croatian sample. More precisely, testing the proposed model revealed that current management tools use more importantly influence future tools use (i.e., the desire to use and become familiar with management tools) than the percentage of satisfied users.

Further results reveal that the impact of current management tools use on future use (i.e. on the desire to use tools for those employees who already know management tools and the desire to become familiar with management tools for those employees who do not know management tools) is stronger than the impact of satisfaction with management tools. Thus, current management tools use importantly determines the future use of tools by others (i.e. those who have not used or know management tools until recently).

Future use or desire to experience, are dependent upon a synergetic set of (1) rational and irrational, (2) organizational and personal, and (3) external and internal factors [5], [13], [37], [41], [50]. The majority of these factors do not appear in our proposed model due to their complexity and extent of research. Including two possible factors, current management tools use and the percentage of satisfied users, it is revealed that they have a jointly and relatively good explanation power regarding the future use of management tools through the perspective of the desire to use management tools and become familiar with them.

Our findings are in line with findings from general management literature that supported the theory that others' experiences, recommendations, and observations could influence future decisions regarding using, participating, and motivation for use, etc. [17], [20], [53]. In organizations, these are also important behavioral signals from management (e.g., role model for other employees) [9]. Our findings are also in line with similar findings from the marketing field (e.g., previous shopping experiences) [22], [46]. Similar examples are also known from the education practice, like the influence of students' experiences with single classes to influence the choices of future students through recommendations.

It can be summarized that the use and knowing of management tools among employees in Slovenian and Croatian organizations is at a very similar level. Differences are related to the priorities about use of single management tools. Among the most used tools, employees 
in both countries significantly and differently use (especially) outsourcing, mission and vision statements, knowledge management, total quality management, and customer segmentation. Conversely, some new tools, like corporate blogs, radio frequency identification, and customer ethnography, are more intensively used in catching up countries than in highdeveloped societies [12], [41].

In catching up countries (e.g., especially in former transition countries), management tools supporting establishing competitive (e.g., modern, innovative) organizational design are in the forefront in order to be more competitive [6], [26], [33], [38], [56]. Conversely, in organizations in high-developed economies, management tools are aimed at supporting activities related to increase customer satisfaction [27], [45], [48], [49].

Outsourcing has been at the forefront of almost every organizational restructuring during the 1980s in organizations operating in high-developed countries [21], while nowadays it lags behind tools aimed at supporting customer satisfaction [27], [49], clear long-term development, and competitive comparing [24], [49]. In the studied catching up countries, this tool is among the top used; in Slovenia, it is a top-used tool and in Croatia, it is ranked sixth.

Strategic planning has been among one of the top used tools since its appearance in the mid-1960s [36] by organizations in highdeveloped countries [49]. But on the other hand, having strategic planning in both studied countries as 8th ranked indicates a lack of long-term planning and orientation, but a focus of organizational management on short-term gains (e.g., solving current problems).

Total quality management had been in the beginning of the 1990s considered an important source of competitive advantage [42] and frequently used in organizations in high-developed economies [40]. Nowadays, in high-developed organizations, tools aiming to support customer care are in the forefront, while total quality management is not ranked among the top 15 tools [49]. Meanwhile, in studied transition countries, this tool is ranked fifth in Slovenia and ninth in Croatia, indicating again a great need for optimization of all organizational processes. Also, it is evident from another catching up country, Tunisia, that TQM could importantly improve the performance of studied manufacturing organizations [59].
Further, it is seen in organizations in catching up countries that a substantial need to acquire and disseminate knowledge is emphasized due to the importance of knowledge to build a modern, innovative organization [4]. In former transition economies, knowledge management is perceived as an important tool for increasing the competitiveness of organizations and the enhancement of business processes [6], [44], [56]. In that framework [33], for example, knowledge management is characterized as a tool that will importantly determine the near future of Czech organizations. In high-developed societies, knowledge management is currently not among the top 10 used management tools [49].

Comparing different regions, in catching up countries it is evident there is a substantial lack of focus on customer service, which is of huge importance in nowadays economics in order to fulfill heightening needs of customers [27]. Poor consideration of various tools regarding satisfying customers in former transition economies has its roots in formerly self-sufficient (e.g. central planned) economics systems where no concurrent pressures were present. This tradition has been staying in organizations since the transition process began [26], [29], [30].

Giving priority to management tools aiming to support optimization of organizations in catching up economies (e.g. former transition organizations) clearly indicates the need for substantial organizational transformation in organizations in these economies [12], [29], [30], [37], [38]. This reveals a lag of former transitional organizations behind those in most developed societies where all forces are targeted toward increasing customer satisfaction [49]. This allows us to conclude that organizations in transitional economies have not yet completely finished their reorganization processes in order to become more competitive [29], [30].

In the near future, we can expect that the pattern of management tools use in catching up countries will become much like those patterns from well-developed market economies. This assumption is based on our findings that the current use of management tools influences their future use. But also high-developed economies will make progress. Will there still be the same tools at the pedestal? If not, then catching up economies will (again) be lagging behind. 


\section{Conclusion}

The proposed model for predicting future management tools use based on the information-perception-action link and theory of planned behavior presupposes that the impact of current management tools use will positively influence their future use by employees in organizations. This paper's results revealed that current management tools use has a positive influence on their future use, while the impact of the current percentage of satisfied users with management tools on their future use is very weak. Those findings are supported with results from the Slovenian sample, while in majority are not supported with results from the Croatian sample. Management tools use among employees in Slovenian and Croatian organizations is at a very similar level, while differences are related to the priorities about use of single management tools. A comparison of actual state management tools use in catching up countries and high-developed economies reveals different priorities in using management tools. In high-developed economies, tools aimed to support customer satisfaction are in the forefront, whereas in catching up countries (studied are two former transitional economies) tools aimed at supporting optimization processes in organizations are in the forefront. This is an indicator that organizations in former transition economies have not yet finished their reorganization triggered by the transition process in order to become highly competitive. Based on our findings that the current use of management tools influences their future use, we can assume that a pattern of management tools use in catching up countries will become like those in high-developed economies. The next step in further research could be testing the model for single management tools in two studies of countries. Further, the model and comparison pattern of management tool use could be carried out in other countries.

\section{References}

[1] AJZEN, I. and FISHBEIN, M. Understanding Attitudes and Predicting Social Behavior. Englewood Cliffs, NJ: Prentice-Hall, 1980. ISBN 978-0139364358.

[2] ARMSTRONG, M. A Handbook of Management Techniques: A Comprehensive Guide to Achieving Managerial Excellence and Improved Decision Making. London: Kogan
Page, 2006. ISBN 0-7494-4766-4.

[3] ARNOLD, J., SILVESTER, J., PATTERSON, F., ROBERTSON, I., COPPER, C. and BURNES, B. Work Psychology: Understanding Human Behaviour in the Workplace. Harlow: Prentice Hall, 2005. ISBN 978-0-273-71121-6.

[4] BECERRA-FERNANDEZ, I., GONZALEZ, A. and SABHERWAL, R. Knowledge Management: Challenges, Solutions, and Technologies. New Jersey, NJ: Pearson-Prentice Hall, 2004. ISBN 9780131016064.

[5] BUCHANAN, F. and HUCZNYSKI, A. Organizational Behaviour. Harlow: Pearson, 2010. ISBN 978-0-273-72822-1.

[6] BUREŠ, V. Conceptual Perspective of Knowledge Management. $E+M$ Ekonomie a Management. 2009, Vol. 12, Iss. 2, pp. 84-96. ISSN 1212-3609.

[7] BYRNE, B. M. Structural Equation Modeling with Amos. New York, NY: Routledge, 2010. ISBN 978-0805841046.

[8] CHEN, M. F. and MAU, L. H. The Impacts of Ethical Sales Behaviour on Customer Loyalty in the Life Insurance Industry. Service Industries Journal. 2009, Vol. 29, Iss. 1, pp. 59-74. ISSN 0264-2069. doi:10.1080/02642060802116339.

[9] COLLINS, J. and PORRAS, J. I. Built to Last: Successful Habits of Visionary Companies. New York, NY: Harper Collins Publishers, 2002. ISBN 978-0060516406.

[10] COOPER, C. L. and ARGYRIS, C. The Concise Blackwell Encyclopedia of Management. Malden: Blackwell, 1998. ISBN 0-631-20885-2.

[11] COOPER, R. G. and KLEINSCHMIDT, E. $\mathrm{J}$. Benchmarking the Firms Critical Success Factors in New Product Development. Journal of Product Innovation Management. 1995, Vol. 12, Iss. 5, pp. 374-391. ISSN 0737-6782. doi:10.1016/0737-6782(95)00059-3.

[12] DABIC, M., POTOCAN, V., NEDELKO, Z. and MORGAN, T. R. Exploring the Use of 25 Leading Business Practices in Transitioning Market Supply Chains. International Journal of Physical Distribution \& Logistics Management. 2013, Vol. 43, Iss. 10, pp. 833-851. ISSN 09600035. doi:10.1108/updlm-10-2012-0325.

[13] DAFT, R. L. Management. Fort Worth, TX: The Dryden Press, 2000. ISBN 0-03-025967-3. [14] DAVENPORT, T. H. and SHORT, J. E. The New Industrial-Engineering - Information Technology and Business Process Redesign. Sloan Management Review. 1990, Vol. 31, Iss. 4, pp. 11-27. ISSN 0019-848X. 
[15] DESSLER, G. Management: Principles and Practices for Tomorrow's Leaders. Upper Saddle River, NJ: Prentice-Hall, 2004. ISBN 0-13-120972-8.

[16] DIXON, N. M. The Organizational Learning Cycle: How We Can Learn Collectively. Gower: Aldershot, 1999. ISBN 978-0566080586.

[17] ENGLAND, G. W. Personal Value Systems of American Managers. Academy of Management Journal. 1967, Vol. 10, Iss. 1, pp. 53-68. ISSN 0001-4273.

[18] ESKILDSEN, J. and KRISTENSEN, K. Customer Satisfaction and Customer Loyalty as Predictors of Future Business Potential. Total Quality Management \& Business Excellence. 2008, Vol. 19, Iss. 7-8, pp. 843-853. ISSN 14783363. doi:10.1080/14783360802159501.

[19] FARNDALE, E., PAAUWE, J. and HOEKSEMA, L. In-Sourcing HR: Shared Service Centres in the Netherlands. International Journal of Human Resource Management. 2009, Vol. 20, Iss. 3, pp. 544-561. ISSN 09585192. doi:10.1080/09585190802707300.

[20] HAMBRICK, D. C. and MASON, P. A. Upper Echelons - the Organization as a Reflection of Its Top Managers. Academy of Management Review. 1984, Vol. 9, Iss. 2, pp. 193-206. ISSN 0363-7425. doi:10.2307/258434.

[21] HARRISON, B. and KELLEY, M. R. Outsourcing and the Search for Flexibility. Work Employment and Society. 1993, Vol. 7, Iss. 2, pp. 213-235. ISSN 0950-0170. doi:10.1177/095001709372003.

[22] HART, C., FARRELL, A. M., STACHOW, G., REED, G. and CADOGAN, J. W. Enjoyment of the Shopping Experience: Impact on Customers' Repatronage Intentions and Gender Influence. Service Industries Journal. 2007, Vol. 27, Iss. 5, pp. 583-604. ISSN 02642069. doi:10.1080/02642060701411757.

[23] HO, R. Handbook of Univariate and Multivariate Data Analysis and Interpretation with Spss. Boca Raton, FL: Chapman \& Hall/ CRC, 2006. ISBN 978-1584886020.

[24] JERMAN, D. and ZAVRSNIK, B. The Model of Marketing Communications Effectiveness: Empirical Evidence from Slovenian Businessto-Business Practice. Journal of Business Economics and Management. 2012, Vol. 13, Iss. 4, pp. 705-723. ISSN 1611-1699. doi:10.38 46/16111699.2011.620163.

[25] KAPLAN, R. S. and NORTON, D. P. Mastering the Management System. Harvard Business Review. 2008, Vol. 86, Iss. 1, pp. 62-77. ISSN 0017-8012.
[26] KIEZUN, W. Management in Socialist Countries: USSR and Central Europe. New York: Walter DeGruyter, 1991. ISBN 978-0899251660. [27] KIM, S. Y., JUNG, T. S., SUH, E. H. and HWANG, H. S. Customer Segmentation and Strategy Development Based on Customer Lifetime Value: A Case Study. Expert Systems with Applications. 2006, Vol. 31, Iss. 1, pp. 101-107. ISSN 0957-4174. doi:10.1016/j. eswa.2005.09.004.

[28] KOCOUREK, A., BEDNAROVA, P. and LABOUTKOVA, $S$. The Linkages between Human Development and Economic, Social, and Political Dimension of Globalization. E+M Ekonomie a Management. 2013, Vol. 16, Iss. 2, pp. 10-21. ISSN 1212-3609.

[29] KOZMINSKI, A. K. Anatomy of Systemic Change Polish Management in Transition. Communist and Post-Communist Studies. 2008, Vol. 41, Iss. 3, pp. 263-280. ISSN 0967067X. doi:10.1016/j.postcomstud.2008.06.006. [30] LANG, R., SZABO, E., CATANA, G. A., KONECNA, Z. and SKALOVA, P. Beyond Participation? - Leadership Ideals of Future Managers from Central and East European Countries. Journal for East European Management Studies. 2013, Vol. 18, Iss. 4, pp. 482-511. ISSN 0949-6181.

[31] LEECH, N. L. and ONWUEGBUZIE, A. J. An Array of Qualitative Data Analysis Tools: A Call for Data Analysis Triangulation. School Psychology Quarterly. 2007, Vol. 22, Iss. 4, pp. 557-584. ISSN 1045-3830. doi:10.1037/10453830.22.4.557.

[32] MALEFYT, T. D. Understanding the Rise of Consumer Ethnography: Branding Technomethodologies in the New Economy. American Anthropologist. 2009, Vol. 111, Iss. 2, pp. 201-210. ISSN 0002-7294. doi:10.1111/ j.1548-1433.2009.01113.x.

[33] MARESOVA, P. Knowledge Management in Czech Enterprises. E+M Ekonomie a Management. 2010, Vol. 13, Iss. 1, pp. 131144. ISSN 1212-3609.

[34] MCKENNA, E. Business Psychology and Organizational Behaviour. New York: Psychology Press, 2012. ISBN 0-86377-667-1. [35] MEIDUTE, I., DAVIDAVICIENE, V. and RAUDELIUNIENE, J. Research on Applying Radio Frequency Identification Technology at Lithuanian Companies. In: GINEVICIUS, R., RUTKAUSKAS, A. V., STANKEVICIENE, J. (Eds.). 7th International Scientific Conference Business and Management 2012. Vilnius: 
Vilnius Gediminas Technical Univ Press, Technika. 2012, pp. 989-996.

[36] MINTZBERG, H. The Fall and Rise of Strategic-Planning. Harvard Business Review. 1994, Vol. 72, Iss. 1, pp. 107-114. ISSN 0017-8012. [37] NEDELKO, Z. and POTOCAN, V. The Role of Management Innovativeness in Modern Organizations. Journal of Enterprising Communities.2013, Vol. 7, Iss. 1, pp. 36-49. ISSN 1750-6204. doi:10.1108/17506201311315590.

[38] NEWMAN, K. L. Organizational Transformation During Institutional Upheaval. Academy of Management Review. 2000, Vol. 25, Iss. 3, pp. 602-619. ISSN 0363-7425. doi:10.2307/259313.

[39] PAL, S. K. and KAPUR, V. The Gradual Adoption \& Maturity of Corporate Blogs. In: SOLIMAN, K. S. (Ed.). Creating Global Economies through Innovation and Knowledge Management: Theory \& Practice. Norristown: Int Business Information Management AssocIbima, 2009. Vols. 1-3. pp. 1295-1299. ISBN 978-0-9821489-1-4.

[40] PORTER, M. E. What Is Strategy? Harvard Business Review. 1996, Vol. 74, Iss. 6, pp. 6178. ISSN 0017-8012.

[41] POTOCAN, V., NEDELKO, Z. and MULEJ, $M$. Influence of Organizational Factors on Management Tools Usage in Slovenian Organizations. Inzinerine Ekonomika-Engineering Economics. 2012, Vol. 23, Iss. 3, pp. 291-300. ISSN 1392-2785. doi:10.5755/j01.ee.23.3.1933.

[42] POWELL, T. C. Total Quality Management as Competitive Advantage - a Review and Empirical-Study. Strategic Management Journal. 1995, Vol. 16, Iss. 1, pp. 15-37. ISSN 0143-2095. doi:10.1002/smj.4250160105.

[43] QUINN, J. B. and HILMER, F. G. Strategic Outsourcing. Sloan Management Review. 1994, Vol. 35, Iss. 4, pp. 43-55. ISSN 0019-848X.

[44] RAUDELIŪNIENE், J., MEIDUTĖ, I. and MARTINAITIS, G. Evaluation System for Factors Affecting Creativity in the Lithuanian Armed Forces. Journal of Business Economics and Management. 2012, Vol. 13, Iss. 1, pp. 148166. ISSN 1611-1699. doi:10.3846/16111699.2 011.639797.

[45] REICHHELD, F. F. Loyalty-Based Management. Harvard Business Review. 1993, Vol. 71, Iss. 2, pp. 64-73. ISSN 0017-8012.

[46] RICH, G. A. The Sales Manager as a Role Model: Effects on Trust, Job Satisfaction, and Performance of Salespeople. Journal of the Academy of Marketing Science. 1997,
Vol. 25, Iss. 4, pp. 319-328. ISSN 0092-0703. doi:10.1177/0092070397254004.

[47] RIGBY, D. Management Tools and Techniques: A Survey. California Management Review. 2001, Vol. 43, Iss. 2, pp. 139-159. ISSN 0008-1256.

[48] RIGBY, D. K. Management Tools 2011: An Executive's Guide [online]. Bain\&Company, 2011 [cit. 2012-05-10]. Available from: http://www.bain.com/publications/articles/ management-tools-2011-executives-guide.aspx. [49] RIGBY, D. K. and BILODEAU, B. Management Tools and Trends 2009 [online]. Bain\&Company, 2009 [cit. 2012-05-10]. Available from: http://www.bain.com/publications/articles/ management-tools-and-trends-2009.aspx.

[50] RUE, L. W. and BYARS, L. L. Management: Skills and Application. Boston: Irwin, 1992. ISBN 0-256-11002-6.

[51] SAPKAUSKIENE, A. and LEITONIENE, $S$. The Concept of Time-Based Competition in the Context of Management Theory. Inzinerine Ekonomika-Engineering Economics. 2010, Vol. 21, Iss. 2, pp. 205-213. ISSN 1392-2785.

[52] SAROTAR-ZIZEK, S., MILFELNER, B. and CANCER, V. Measurement of Employees Subjective Well-Being as an Aim of Social Responsibility. Systemic Practice and Action Research. 2013, Vol. 26, Iss. 6, pp. 549-560. ISSN 1094-429X. doi:10.1007/s11213-013-9303-y.

[53] SCHERMERHORN, J. R. Management. New Jersey, NJ: John Wiley \& Sons, 2008. ISBN 978-0470-53051-1.

[54] SCHWARTZ, S. H. and BILSKY, W. Toward a Universal Psychological Structure of Human-Values. Journal of Personality and Social Psychology. 1987, Vol. 53, Iss. 3, pp. 550-562. ISSN 0022-3514. doi:10.1037//00223514.53.3.550.

[55] SKOKAN, K. The History of Modern Business. E+M Ekonomie a Management. 2013, Vol. 16, Iss. 4, pp. 170-170. ISSN 1212-3609.

[56] SLAVICEK, V. Enhancing Business Process Management with Knowledge. E+M Ekonomie a Management. 2011, Vol. 14, Iss. 1, pp. 123134. ISSN 1212-3609.

[57] SUTHERLAND, J. and CANWELL, D. Key Concepts in Management. New York: Palgrave MacMillan, 2004. ISBN 1-4039-1533-4.

[58] VAN ASSEN, M., VAN DEN BERG, G. and PIETERSMA, P. Key Management Models: The 60+Models Every Manager Needs to Know. Harlow: Prentice Hall, 2009. ISBN 978-0-27375131-1. 


\section{Ekonomika a management}

[59] WALI, S. and BOUJELBENE, Y. Cultural Influences on TQM Implementation and Financial Performance in Tunisian Firms. $E+M$ Ekonomie a Management. 2011, Vol. 14, Iss. 3, pp. 30-45. ISSN 1212-3609.

[60] WREN, D. The Evolution of Management Thought. New York: John Wiley, 1994. ISBN 0-471-59752-X.

[61] YAMMARINO, F. J., DIONNE, S. D., CHUN, J. U. and DANSEREAU, F. Leadership and Levels of Analysis: A State-of-the-Science Review. Leadership Quarterly. 2005, Vol. 16, Iss. 6, pp. 879-919. ISSN 1048-9843. doi:10.1016/j. leaqua.2005.09.002.

[62] ZAVADSKA, Z., ZAVADSKY, J. and SIROTIAKOVA, M. Process Model and Its Real Application in the Selected Management Areas. E+M Ekonomie a Management. 2013, Vol. 16, Iss. 1, pp. 113-127. ISSN 1212-3609.
Zlatko Nedelko, Ph.D.

University of Maribor

Faculty of Economics and Business

Department of Management and Organization zlatko.nedelko@uni-mb.si

Vojko Potocan, Ph.D.

University of Maribor

Faculty of Economics and Business Department of Management and Organization vojko.potocan@uni-mb.si

\author{
Marina Dabić, Ph.D. \\ University of Zagreb \\ Faculty of Economics \\ Department of International Economics \\ mdabic@efzg.hr
}




\section{CURRENT AND FUTURE USE OF MANAGEMENT TOOLS}

\section{Zlatko Nedelko, Vojko Potocan, Marina Dabić}

This paper examines the use of management tools among Slovenian and Croatian employees, with the main focus on linkages between the current use of management tools and patterns of its future use. The authors developed and tested a model for predicting the future use of management tools based on the current use of tools by employees in organizations, underlying assumptions of the theory of planned behavior and the information-perception-behavior link. Descriptive statistics suggest that there are differences in management tools use patterns among Slovenian and Croatian employees. Among the most used tools, employees in both countries significantly and differently use (especially) outsourcing, mission and vision statements, knowledge management, total quality management, and customer segmentation. Using structural equation modeling for testing the proposed relations in the developed model on samples of Slovenian and Croatian employees reveals that the current use of tools plays an important role in predicting the future use of tools in Slovenian organizations, while linkages for the Croatian sample are rather insignificant. More specifically, the current use of management tools has a positive influence on the future use of management tools, while the impact of the current percentage of satisfied users with management tools is very weak. Further, a comparison of results with international data reveals differences in the patterns of management tools use between former catching up countries (studied are two former transition economies) and economies with a longer tradition in the market economy. Based on the current state of management tools use, linkages between their current and future use, and patterns of tools use in high-developed economies, the authors speculate about the future pattern of management tools use in catching up countries based on experiences from high-developed market economies. Those assumptions represent a building block for boosting the use of management tools in organizations in catching up economies, and thus helping those organizations to reduce the gap between them and most developed organizations.

Key Words: Croatia, current use, future use, management tools, perception, planned behavior, Slovenia, pattern of use.

JEL Classification: D23, M10.

DOI: 10.15240/tul/001/2015-1-003 